\title{
EVALUASI INSTALASI PENGOLAHAN AIR LIMBAH INDUSTRI PENGOLAHAN MAKANAN
}

\author{
Arifudin, Setiyono, Fajar Eko Priyanto, Susi Sulistia \\ Pusat Teknologi Lingkungan, TPSA, BPPT Gedung Geostech820, Kawasan Puspiptek, Serpong15314, Tangerang Selatan, \\ Indonesia \\ E-mail: arifudinbt108@gmail.com; setiyonoi@hotmail.com; fajar.eko@bppt.go.id; susi.sulistia@bppt.go.id
}

\begin{abstract}
ABSTRAK
Industri Pengolahan Makanan, dalam mengolah air limbah telah memiliki sarana pengolahan air limbah berupa IPAL dengan mengkombinasikan teknik elektrokoagulasi dan filtrasi (karbon filter). Peningkatan kegiatan produksi yang tidak dibarengi dengan perubahan pada sistem IPAL menyebabkan beban air limbah yang dihasilkan dari kegiatan produksi meningkat. Hal ini menyebabkan air olahan IPAL tidak memenuhi baku mutu air limbah. sehingga perlu dilakukan evaluasi terhadap IPAL yang ada. Tujuan kegiatan ini adalah melakukan evaluasi kinerja dari IPAL Industri Pengolahan Makanan. Dari hasil pengukuran parameter polutan pada air limbah hasil proses elektrokoagulasi di IPAL eksisting adalah nilai COD, BOD dan TSS mengalami penurunan berturut-turut yaitu sebesar $60 \%$ dari $3.083 \mathrm{mg} / \mathrm{L}$ menjadi $1.055 \mathrm{mg} / \mathrm{L} ; 67 \%$ dari $820 \mathrm{mg} / \mathrm{L}$ menjadi $273 \mathrm{mg} / \mathrm{L}$ dan $55 \%$ dari $398 \mathrm{mg} / \mathrm{L}$ menjadi $178 \mathrm{mg} / \mathrm{L}$. tingginya nilai tersebut menunjukan bahwa beban polutan pada air limbah hasil proses elektrokoagulasi masih tinggi. Hal ini menyebabkan air olahan hasil IPAL masih diatas baku mutu air limbah yaitu dengan nilai COD, BOD dan TSS berturut-turut $751 \mathrm{mg} / \mathrm{L}, 194 \mathrm{mg} / \mathrm{L}$ dan TSS $164 \mathrm{mg} / \mathrm{L}$.
\end{abstract}

Kata Kunci: Limbah cair, industri pengalahan makanan, elektrokoagulasi, karbon filter

\section{EVALUATION OF THE FOOD PROCESSING INDUSTRY WASTEWATER TREATMENT PLANT}

\author{
Arifudin, Setiyono, Fajar Eko Priyanto, Susi Sulistia \\ Center for Environmental Technology, BPPT, Puspiptek Area, South Tangerang, 15314, Indonesia \\ Email: arifudinbtl08@gmail.com; setiyonoi@hotmail.com; fajar.eko@bppt.go.id; susi.sulistia@bppt.go.id
}

\begin{abstract}
The Food Processing Industry in treating its wastewater already has a wastewater treatment facility in the form of WWTP by combining electrocoagulation and filtration (carbon filter) techniques. Increased production activities that are not accompanied by changes to the WWTP system cause the burden of wastewater generated from production activities to increase. This causes the WWTP treated water does not meet the wastewater quality standards. so it is necessary to evaluate the existing WWTP. The purpose of this activity is to evaluate the performance of the Food Processing Industry WWTP. From the results of the measurement of pollutant parameters in wastewater from the electrocoagulation process in the existing WWTP, the COD, BOD and TSS values decreased respectively by $60 \%$ from $3,083 \mathrm{mg} / \mathrm{L}$ to $1,055 \mathrm{mg} / \mathrm{L}$; $67 \%$ from $820 \mathrm{mg} / \mathrm{L}$ to $273 \mathrm{mg} / \mathrm{L}$ and $55 \%$ from $398 \mathrm{mg} / \mathrm{L}$ to $178 \mathrm{mg} / \mathrm{L}$. the high value indicates that the burden of pollutants in wastewater resulting from the electrocoagulation process is still high. This causes the treated WWTP water is still above the wastewater quality standard, namely the COD, BOD and TSS values respectively $751 \mathrm{mg} / \mathrm{L}, 194 \mathrm{mg} / \mathrm{L}$ and TSS $164 \mathrm{mg} / \mathrm{L}$.
\end{abstract}

Keywords: Wastewater, food defeating industry, electrocoagulation, carbon filter.

\section{PENDAHULUAN}

Industri pengolahan makanan merupakan industri yang bergerak dalam bidang pengolahan makanan. Industri ini dalam mengolah makanannya menggunakan bahan baku seperti daging ayam, daging sapi, sayur-sayuran, tepung terigu, minyak dan bumbu-bumbu alami menjadi bahan setengah saji, kemudian disuplai ke berbagai gerai atau restoran di daerah DKI Jakarta dan sekitarnya.

Industri ini dalam menjalankan kegiatannya menggunakan air bersih untuk keperluan produksi maupun untuk domestik dan sebanyak $80 \%$ dari air bersih yang digunakan akan dibuang kelingkungan sebagai air limbah (Astika et al, 2017). 
Air limbah hasil proses produksi industri pengolahan makanan ini mengandung bahan organik dan lemak/minyak dalam jumlah besar. Bila limbah ini masuk ke badan perairan dapat menutupi permukaan air dan menghambat terjadinya transfer oksigen dari udara ke dalam badan air. Kondisi ini dapat menyebabkan berkurangnya ketersedian oksigen di dalam air dan berakibat matiya ikan dan hewan air lainnya. Selain itu juga dapat menghasilkan bau busuk sebagai akibat terjadinya penguraian bahan organik komplek oleh bakteri anaerobik menjadi gas metan, sulfida dan gas lainnya yang menimbulkkan bau tidak sedap

Untuk mengolah air limbahnya. Saat ini indsutri pengolahan makanan ini telah memiliki sarana pengolahan air limbah berupa IPAL yang menggabungkan teknologi elektrokoagulasi dengan filtrasi (filter karbon). Namun seiring dengan beriringnya waktu dan adanya peningkatan produksi menyebabkan air olahan IPAL seringkali melampau baku mutu air limbah yang ditetapkan oleh pemerintah yaitu PermenLH No 5 Tahun 2014 Tentang Baku Mutu Air Limbah Untuk Industri Pengolahan Daging. Untuk memperbaiki kualitas air olahan IPAL, perlu dilakukan evaluasi dari kinerja IPAL. Hasil evaluasi ini selanjutnya digunakan sebagai dasar dalam penyusunan redesain IPAL eksisting.

Tujuan kegiatan ini adalah Melakukan evaluasi kinerja dari IPAL Industri Pengolahan Makanan.

\section{METODE PENELITIAN}

Kegiatan evaluasi Instalasi Pengolahan Air Limbah (IPAL) Industri Pengolahan Makanan dimulai dengan melakukan survei kondisi eksisting dari sumber air limbah, jaringan air limbah, oil trap dan unit oparasi IPAL yang ada. Juga dilakukan pengambilan contoh air limbah di oil trap, bak ekualisasi, bak sedimentasi dan outlet IPAL untuk dianalisa di Laboratorium Lingkungan. Pengukuran ini dilakukan bertujuan untuk mengetahui kadar kontaminan pada masingmasing lokasi.

Pengambilan contoh air limbah di outlet IPAL dilakukan dengan menggunakan peralatan sebagai berikut:

1. Peralatan sampling air, seperti: gayung plastik, botol plastik, botol kaca, tool box, ice pack dan setting GPS untuk melihat detail lokasi sampling, sehingga dapat dilakukan pemantauan berulang dikemudian hari untuk melihat peningkatan atau penurunan air olahan IPAL.

2. Peralatan pendukung lainnya seperti lembar catatan lapangan, alat tulis, sarung tangan, masker dan lain sebagainnya.

3. Selain pengambilan contoh air untuk di analisa di Laboratorium, juga dilakukan pengukuran secara in-situ dilapangan dengan menggunakan peralatan $\mathrm{pH}$ meter portable.

Parameter kimia yang diamati adalah $\mathrm{pH}$ air limbah yang diukur menurut metode elektrometri (ASTM D 4972 - 01), total suspended solid (TSS) ditetapkan dengan metode SNI 06-6989.3-2004, Amoniak diukur dengan menggunakan metode Std.Methods (Ed.21). 4500-NH3, minyak lemak ditetapkan dengan menggunakan metode SNI 066989.10-2004, BOD dietetapkan menurut metode Std. Methods (Ed.21).5210 dan COD diukur dengan menggunakan metode SNI 06-6989.22009.

\section{HASIL DAN PEMBAHASAN}

Dalam mengolah air limbahnya, Industri Pengolahan Makanan di Jakarta ini telah memiliki sarana berupa IPAL yang mengkombinasikan teknologi elektrokoagulasi dengan filter karbon. Berdasarkan hasil analisis paramter polutan di laboratorium disebutkan bahwa air limbah hasil proses elektrokoagulasi masih memiliki kandungan COD, BOD dan TSS yang tinggi dan terlihat sangat keruh. Hal ini menunjukan bahwa beban cemaran air limbah masih tinggi sehingga menambah beban kinerja pada proses filter karbon dalam menyisihkan TSS yang terbawaah air limbah.

Berikut ini rincian dari hasil suvei pada masing-masing unit IPAL eksisting, yaitu:

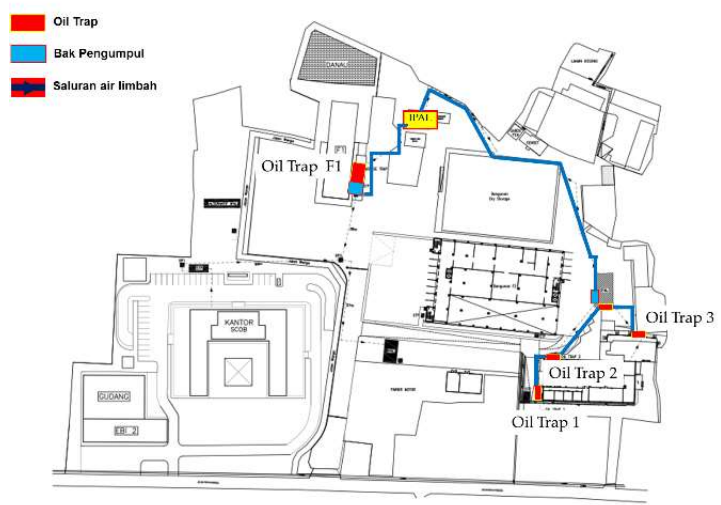

Gambar 1. Peta posisi beberapa Oil Trap di Industri Pengolahan Makanan

\subsection{Oil Trap}

Air limbah yang dihasilkan dari proses produksi seperti proses pencucian bahan baku, perebusan daging, sayuran dan pencucian peralatan produksi mengandung lemak dan minyak. Air limbah ini sebelum dialirkan menuju ke IPAL terlebih dahulu dilakukan pemisahan minyak dan lemak di unit oil trap. Over flow air limbah dialirkan secara gravimetri menuju ke bak pengumpul. Dari bak pengumpul air limbah 
dipompa menuju IPAL untuk diolah secara bersama-sama dengan sumber air limbah lainnya. Berdasarkan hasil survei dilapangan diketahui bahwa pada umumnya di bilik 1 pada bak oil trap ditemukan sejumlah lumpur dalam jumlah yang besar atau memenuhi 0,5 hingga $0,75 \%$ dari volume bilik 1 . Selain itu juga ditemukan sejumlah besar minyak/lemak yang mengapung dipermukaan air dan tertahan di oil trap. Bila lemak/minyak yang mengapung dan lumpur organik ini jarang dilakukan pengambilan dapat menyebabkan terjadinya proses penguraian bahan organik seperti protein, lemak/minyak dan karbohidrat menjadi bahan yang lebih sederhana. Lemak akan dihidrolisis menjadi asam lemak yang selanjutnya diubah menjadi asam propionat (Fessenden dan Fessenden, 1995). Protein dihidrolisis menjadi asam amino yang selanjutnya diubah menjadi asam keto dan karbohidrat dihidrolisis menjadi asam keto dan alkohol. Asam keto yang berasal dari protein dan karbohidrat diubah menjadi asam piruvat, yang selanjutnya diubah lagi menjadi asam laktat, asam propionat dan asam butirat (Said et al. 2005). Senyawa-senyawa tersebut disamping menyebabkan air limbah menjadi bersifat asam juga menghasilkan bau yang tidak sedap.

Berdasarkan hasil analisa pada sampel yang diambil di oil trap menunjukan bahwa air limbah segar yang masuk ke dalam oil trap memiliki nilai $\mathrm{pH}$ berkisar antara $6-6,53$. Sedangkan air limbah di outlet oil trap memiliki nilai $\mathrm{pH}$ yang lebih rendah yaitu berkisar antara 4,19 -5,83 atau bersifat asam (Gambar 2). Selain itu pada umumnya air limbah di outlet oil trap memiliki nilai TSS lebih rendah dibandingkan di inlet oil trap, kecuali pada pada oil trap 2. Hal ini dikarenakan ada sumber air limbah baru yang masuk ke oulet oil trap (Gambar 3).

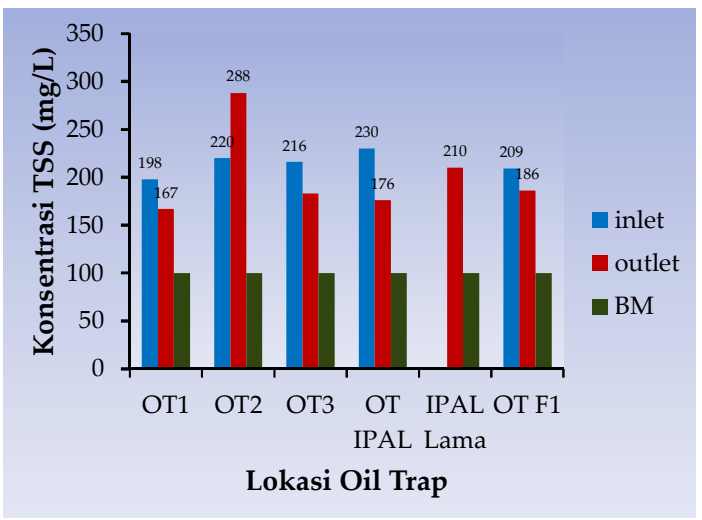

Gambar 2. Grafik hasil analisa parameter TSS di Bak Oil Trap (OT)

Penurunan nilai padatan tersuspensi (TSS) mengindikasikan terjadinya proses pengendapan di dalam bak oil trap. Endapan yang terbentuk berasal dari pasir, kotoran, padatan tersuspensi (TSS) yang terbawah air limbah dan bahan organik hasil pembusukan lemak/minyak oleh bakteri.

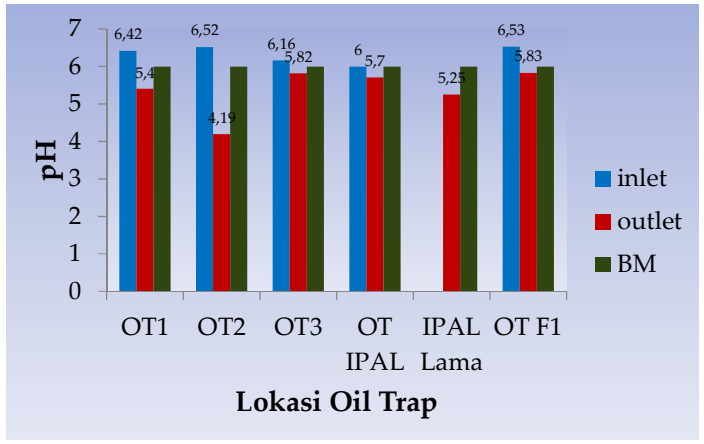

Gambar 3. Grafik hasil analisa parameter $\mathrm{pH}$ di bak oil trap (OT)

\subsection{Bak Ekualisasi}

Bak ekualisasi bukan merupakan suatu proses pengolahan tetapi merupakan suatu cara/teknik untuk meningkatkan efektifitas dari proses pengolahan selanjutnya. Adapun kegunaan dari ekualisasi adalah:

1. Mengkontinyukan debit limbah yang akan diolah di IPAL (membagi dan meratakan volume pasokan (influent) untuk masuk pada proses kimia.

2. Menstabilkan karakteristik limbah (meratakan variable) \& fluktuasi dari beban organik untuk menghindari shock loading pada sistem pengolahan biologi.

3. Meratakan $\mathrm{pH}$ untuk meminimalkan kebutuhan kimia pada proses netralisasi.

4. Meratakan kandungan padatan (suspended solid, koloidal, dan lain sebagainya) untuk meminimalkan kebutuhan kimia pada proses koagulasi dan flokulasi, sehingga dilihat dari fungsinya tersebut, unit bak ekualisasi sebaiknya dilengkapi dengan mixer, atau secara sederhana konstruksi/peletakan dari pipa inlet dan outlet diatur sedemikian rupa sehingga menimbulkan efek turbulensi mixing. Idealnya pengeluaran (discharge) dari ekualisasi dijaga konstan selama periode 24 jam, biasanya dengan cara pemompaan maupun cara-cara lain yang memungkinkan.

Berdasarkan hasil analisa di laboratorium, seperti diperlihatkan pada Tabel 1. diketahui bahwa air limbah di bak ekualisasi bersifat asam dengan nilai $\mathrm{pH}$ sebesar 5 . Nilai COD sangat tinggi yaitu sebesar $3.083 \mathrm{mg} / \mathrm{L}$. Nilai COD yang tinggi mengindikasikan semakin besar pencemaran yang terjadi. Selain itu air limbah di bak ekualisasi juga sangat keruh hal ini dibuktikan 
dengan kandungan padatan tersuspensi yang cukup tinggi yaitu sebesar 398 mg/L.

Tabel 1. Kualitas Air di Bak Ekualisasi

\begin{tabular}{lccc}
\hline Parameter & Satuan & Ekualisasi & BM* \\
\hline BOD & $(\mathrm{mg} / \mathrm{L})$ & 820 & 125 \\
COD & $(\mathrm{mg} / \mathrm{L})$ & 3083 & 250 \\
TSS & $(\mathrm{mg} / \mathrm{L})$ & 398 & 100 \\
Amoniak & $(\mathrm{mg} / \mathrm{L})$ & 26,3 & 10 \\
Minyak & $(\mathrm{mg} / \mathrm{L})$ & 9 & 10 \\
\&Lemak & & 5 & $6-9$ \\
pH & - & 5 & \\
* Permen LH No 5 Tahun 2014, Baku Mutu untuk Industri \\
Pengolahan daging
\end{tabular}

\subsection{Proses Elektrokoagulasi}

Elektrokoagulasi adalah proses penggumpalan dan pengendapan pertikelpartikel halus yang terdapat dalam air dengan menggunakan energi listrik. Elekrokoagulasi ini merupakan gabungan dari proses elektrokimia, flokulasi, dan koagulasi. Dimana Koagulasi merupakan suatu proses pengolahan air dengan menggunakan sistem pengadukan cepat sehingga dapat mereaksikan koagulan (bahan kimia) tertentu secara seragam ke seluruh bagian air limbah dalam suatu bak sehingga dapat membentuk flok-flok atau butiran-butiran yang berukuran lebih besar dan dapat diendapkan. Sedangkan Flokulasi adalah metode untuk memperbesar ukuran flok-flok dari hasil koagulasi dengan cara pengadukan lambat

Prinsip kerja dari proses elektrokoagulasi adalah air limbah dari bak ekualiasi dipompa dengan menggunakan pompa celup menuju reaktor elektrokoagulasi. Di dalam reaktor ini sebuah arus listrik dialirkan ke elektroda logam (alumunium). Aliran listrik ini akan mengoksidasi logam alumunium menjadi logam kation (Al3+). Sedangkan air akan mengalami reduksi menghasilkan gas hidrogen $(\mathrm{H} 2)$ dan ion hidroksida (OH-) Persamaan reaksinya adalah sebagai berikut :

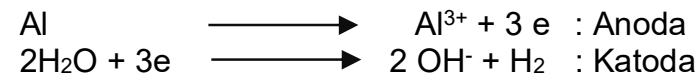

Kation $\mathrm{Al} 3+$ menghidrolisis di dalam air membentuk sebuah hidroksi [Al(OH3] yang berfungsi sebagai koagulan. Kation bermuatan tinggi tersebut dapat mendestabilisasi beberapa partikel koloid dengan membentuk polivalen polihidroksi komplek. Senyawa komplek ini mudah diadsorbsi, membentuk aggregat (gumpalan) dengan polutan (Mukimin, 2006).
Pelepasan gas hidrogen akan membantu pencampuran dan pembentukan flok. Flok yang dihasilkan oleh gas hidrogen akan diflotasikan kepermukaan reaktor. Gumpalan yang dihasilkan selanjutnya dipisahkan dan ditampung ke dalam bak penampung lumpur. Sementara filtrat akan dialirkan menuju bak sedimen untuk dilakukan pemisahan padatan yang masih terbawah air limbah.

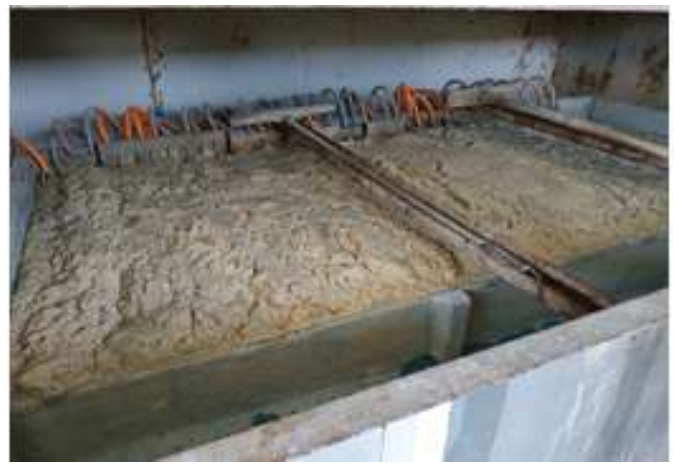

Gambar 4. Kondisi reaktor elektrokoagulasi dengan flok yang terbentuk

Kandungan lemak dan minyak yang terlalu tinggi di dalam air limbah, seringkali menyebabkan proses elektrokogulasi tidak berjalan dengan optimal. Lemak dan minyak yang ada di air limbah dapat menempel dan menutupi permukaan elektroda alumunium. Hal ini menyebabkan proses pelepasan kation alumunium $(\mathrm{Al}(\mathrm{OH}) 3)$ yang berperan penting dalam pembentukan agregat (gumpalan) dengan polutan menjadi terhambat dan menyebabkan kualitas air olahan menjadi menurun atau berada di atas baku mutu air limbah berdasarkan PermenLH No. 5 Tahun 2014 Tentang Baku Mutu Air Limbah untuk Industi Pengolahan Daging.

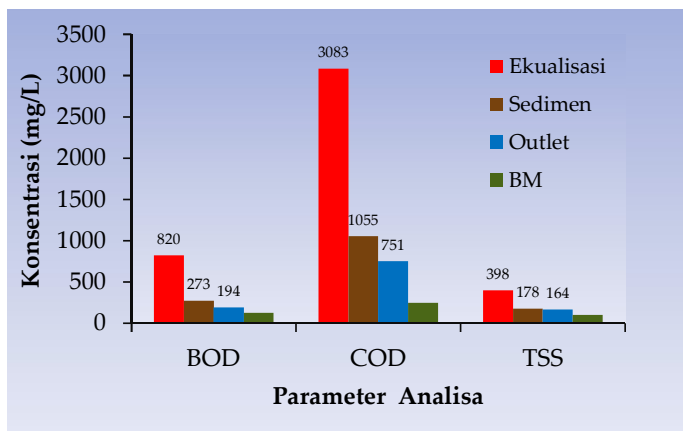

Gambar 5. Grafik hasil analisa parameter BOD, COD dan TSS

Berdasarkan analisa di laboratorium pada sampel outlet bak sedimentasi (Gambar 5)., menunjukan bahwa nilai COD masih tinggi yaitu sebesar $1.055 \mathrm{mg} / \mathrm{L}$ atau mengalami penurunan sebesar $60 \%$ dari sebelumnya yaitu sebesar $3.083 \mathrm{mg} / \mathrm{L}$ dan nilai TSS sebesar $178 \mathrm{mg} / \mathrm{L}$ atau 
mengalami penurunan sebesar 55\% dari sebelumnya sebesar $273 \mathrm{mg} / \mathrm{L}$. Nilai tersebut menunjukan bahwa proses elektrokoagulasi tidak bekerja dengan baik. Hal ini dibuktikan dengan kualitas air di bak sedimentasi masih keruh atau masih mengandung padatan suspensi dalam jumlah yang banyak.

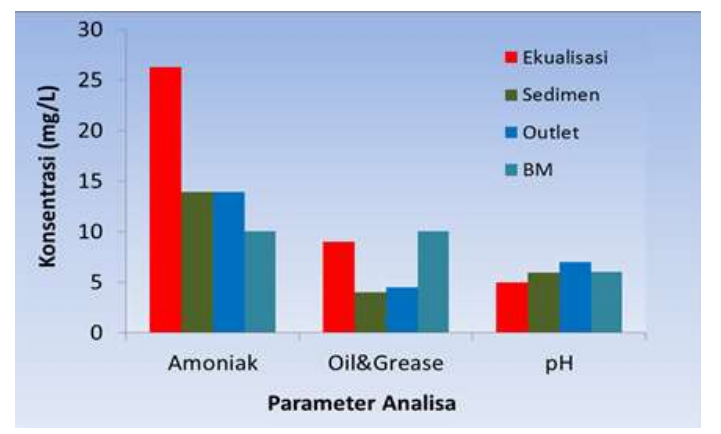

Gambar 6. Grafik hasil analisa parameter amoniak, minyak/lemak dan $\mathrm{pH}$

Pada Gambar 5 disebutkan bahwa, nilai BOD, COD dan TSS outlet IPAL masih tinggi yaitu berturut-turut sebesar $194 \mathrm{mg} / \mathrm{L}, 751 \mathrm{mg} / \mathrm{L}$ dan $164 \mathrm{mg} / \mathrm{L}$ atau masih berada diatas nilai baku mutu air limbah PermenLH No.5 Tahun 2014 Tentang Pengolahan Limbah Industri Pengolahan Daging dengan nilai baku mutu untuk BOD, COD dan TSS berturut-turut adalah $125 \mathrm{mg} / \mathrm{L}, 250$ $\mathrm{mg} / \mathrm{L}$ dan $100 \mathrm{mg} / \mathrm{L}$.

Tingginya nilai tersebut menunjukan bahwa sistem IPAL yang digunakan tidak efektif. Sehingga untuk meningkatkan kualitas air olahan menjadi sesuai baku mutu air limbah perlu dilakukan alternatif pengolahan air limbah, yaitu dengan menggunakan proses kimia (koagulasi dan flokulasi). Proses kimia ini diujicoba di dalam laboratorium dengan jartest.

\subsection{Percobaan Jartest di Laboratorium}

Tujuan melakukan jar test adalah untuk memilih jenis dan dosis bahan kimia (flokulan dan koagulan) yang tepat untuk mengolah air limbah (Suprihatin dan Suparno, 2013). Bahan kimia yang digunakan untuk jartest ini adalah $\mathrm{CaO}$ (kapur tohor), polyalumunium chloride (PAC) dan kuriflok. Kapur tohor $(\mathrm{CaO})$ merupakan bahan kimia yang berfungsi untuk meningkatkan nilai $\mathrm{pH}$ air limbah. Dengan peningkatan $\mathrm{pH}$ air limbah ini proses koagulasi dan flokulasi dapat berjalan. Pada umumnya proses koagulasi dan flokulasi bekerja pada $\mathrm{pH} 8$ - 9. Bahan koagulan seperti PAC banyak digunakan dalam proses penyisian partikel tersuspensi. PAC merupakan sebuah polimer alumunium yang bermuatan positif.
Polimer ini mampu menetralisir muatan negatif dari partikel tersuspensi (koloid) sehingga tarjadi ikatan antara partikel tersuspensi dengan PAC membentuk polivalen polihroksi komplek (flok kecil). Penambahan bahan flokulan seperti kuriflok pada air limbah menyebabkan flok-flok kecil tersebut saling berikatan membentuk flok yang lebih besar sehingga mudah diendapkan di bak sedimentasi.

Berdasarkan analisa di laboratorium menunjukan bahwa air limbah sebelum proses kimia atau jartest bersifat asam dengan nilai $\mathrm{pH}$ sebesar 5 dan memiliki nilai COD dan BOD yang cukup tinggi yaitu berturut - turut sebesar 3.083 $\mathrm{mg} / \mathrm{L}$ dan $398 \mathrm{mg} / \mathrm{L}$. Nilai COD dan BOD yang tinggi mengindikasikan beban polutan cukup tinggi. selain itu air limbah ini juga memiliki nilai TSS (Total Suspended Solid) yang cukup tinggi $398 \mathrm{mg} / \mathrm{L}$.

Tabel 2. Perubahan kandungan parameter polutan sebelum dan sesudah jartest

\begin{tabular}{lccc}
\hline \multicolumn{1}{c}{ Parameter } & $\begin{array}{c}\text { Sebelum } \\
\text { Jartest }\end{array}$ & $\begin{array}{c}\text { Sesudah } \\
\text { Jartest }\end{array}$ & $\begin{array}{c}\text { Efisiensi } \\
(\%)\end{array}$ \\
\hline BOD (mg/L) & 820 & 37 & 95 \\
COD (mg/L) & 3083 & 109 & 96 \\
TSS (mg/L) & 398 & 77 & 81 \\
$\begin{array}{l}\text { Amoniak } \\
(\mathrm{mg} / \mathrm{L})\end{array}$ & 26,3 & 6,49 & 75 \\
$\begin{array}{l}\text { Oil \& grease } \\
(\mathrm{mg} / \mathrm{L})\end{array}$ & 9 & 5,5 & 39 \\
$\mathrm{pH}$ & 5 & 7 & - \\
\hline
\end{tabular}

Dari tabel di atas menunjukan bahwa nilai COD setelah proses jartest mengalami penurunan sebesar $96 \%$ dari $3.083 \mathrm{mg} / \mathrm{L}$ menjadi $109 \mathrm{mg} / \mathrm{L}$, sedangkan nilai TSS mengalami penurunan sebesar $81 \%$ dari $398 \mathrm{mg} / \mathrm{L}$ menjadi 77 mg/L. Penurunan TSS yang cukup signifikan ini menunjukan bahwa banyaknya padatan tersuspensi yang berhasil mengendap.

\subsection{Perbandingan Proses Elektrokoagulasi Dengan Proses Kimia/Jartest}

Pada Tabel 3., dijelaskan bahwa hasil percobaan jartest (koagulasi - flokulasi) mampu menurunkan parameter BOD, COD dan TSS berturut-turut sebesar 95\%, $96 \%$ dan $81 \%$. Sedangkan proses elektrokoagulasi (proses yang saat ini digunakan untuk mengolah air limbah di IPAL eksisting) hanya mampu menurunkan nilai BOD, COD dan TSS berturut-turut sebesar $67 \%$, $66 \%$ dan $55 \%$. Ini menunjukan bahwa proses 
elektrokoagulasi kurang efektif untuk mengolah air limbah dengan kandungan lemak dan minyak yang tinggi. Hal ini disebabkan oleh tertutupnya lapisan elektroda alumunium oleh minyak dan lemak yang terbawa di air limbah. lemak dan minyak di dalam reaktor elektrokoagulasi akan menutupi lapisan katoda. Hal ini menyebabkan lempengan katoda alumunium tidak mampu melepaskan $\mathrm{Al}(\mathrm{OH}) 3$ yang berperan sebagai bahan koagulan yang mampu mengikat kontaminan dan padatan tersuspensi menjadi gumpalan atau flok. Dengan tertutupnya lempengan elektroda alumunium oleh lapisan minyak ini menyebabkan jumlah padatan tersuspensi yang berikatan dengan kation alumunium membentuk flok jumlahnya berkurang sehingga air limbah yang keluar dari proses elektrokoagulasi masih keruh dan masih mengandung padatan tersuspensi yang tinggi.

\section{KESIMPULAN}

Berdasarkan hasil evaluasi IPAL dan analisa kualitas air limbah di bak oil trap, bak ekualisasi, bak sedimentasi dan outlet IPAL, maka dapat disimpulkan beberapa sebagai berikut:

1. Lemak/minyak dan lumpur di bak oil trap jarang dilakukan pengambilan. Hal ini menyebabkan terjadinya penguraian bahan organik yang ada di lumpur maupun yang mengapung menjadi senyawa organik yang bersifat asam dan menghasilkan bau yang tidak sedap.

2. Berdasarkan hasil pengukuran di laboratorium menunjukan bahwa penggunaan proses kimia lebih efektif dalam mengurangi polutan dibandingkan dengan penggunaan proses elektrokoagulasi. Penggunaan proses kimia (koagulasi - flokulasi) mampu menurunkan kadar COD sebesar 96\% yaitu dari $3.083 \mathrm{mg} / \mathrm{L}$ menjadi $109 \mathrm{mg} / \mathrm{L}$. kadar BOD sebesar $95 \%$, yaitu dari $820 \mathrm{mg} / \mathrm{L}$ menjadi $37 \mathrm{mg} / \mathrm{L}$, dan TSS sebesar $81 \%$, yaitu dari $398 \mathrm{mg} / \mathrm{L}$ menjadi $81 \mathrm{mg} / \mathrm{L}$. sedangkan pada proses elektrokoagulasi mampu menurunkan COD sebesar $66 \%$ yaitu dari $3.083 \mathrm{mg} / \mathrm{L}$ menjadi $1.055 \mathrm{mg} / \mathrm{L}$. kadar BOD sebesar $67 \%$, yaitu dari $820 \mathrm{mg} / \mathrm{L}$ menjadi 273 $\mathrm{mg} / \mathrm{L}$, dan TSS sebesar $55 \%$, yaitu dari 398 $\mathrm{mg} / \mathrm{L}$ menjadi $178 \mathrm{mg} / \mathrm{L}$

3. Berdasarkan hasil analisa air limbah yang diambil di oulet IPAL eksisting, masih memiliki kandungan COD, BOD dan TSS yang masih tinggi yaitu berturut-turut sebesar $751 \mathrm{mg} / \mathrm{L}$, $194 \mathrm{mg} / \mathrm{L}$ dan $164 \mathrm{mg} / \mathrm{L}$. nilai tersebut masih di atas baku mutu air limbah bagi usaha dan/atau kegiatan pengolahan daging (PerMen LH No 5 Tahun 2014). Adapun nilai parameter air limbah yang diperbolehkan dibuang di badan perairan berdasarkan PermenLH tersebut adalah nilai COD sebesar $250 \mathrm{mg} / \mathrm{L}$, BOD sebesar $125 \mathrm{mg} / \mathrm{L}$ dan nilai TSS sebesar $100 \mathrm{mg} / \mathrm{L}$.

4. Untuk meningkatkan mutu hasil olahan IPAL, agar outletnya dapat memenuhi standar baku mutu air limbah, maka perlu dilakukan perbaikan/renovasi dan peningkatan kapasitas IPAL menjadi $200 \mathrm{~m}^{3} /$ hari sebagai akibat adanya rencana peningkatan kapasitas produksi.

5. Selain itu perlu dilakukan start up pengoperasian IPAL serta monitoring pengoperasian IPAL hingga kinerja IPAL dapat beroperasi dengan baik sesuai perencanaan dan hasil olahan IPAL dapat memenuhi standar baku mutu sesuai dengan Permen LH RI Nomor 5 Tahun 2014 Tentang Baku Mutu Air Limbah Bagi Usaha Dan/Atau Kegiatan Pengolahan Daging

\section{DAFTAR PUSTAKA}

1. Fessenden, R.J., Fessenden J.S. 1995. Kimia Organik Jilid 1. Erlangga. Jakarta.

2. Nusa I.S, Wahyu W, Arie H, Ewinur C.M., 2002 Aplikasi Teknologi Biofilter Untuk Pengolahan Air Limbah Industri Kecil Tekstil.

3. Astika, A.U.W., Sudarno, \& Zaman, B. (2017). Kajian kinerja bak settler, anaerobic baffled reactor (abr), dan anaerobic filter (af) pada tiga tipe IPAL di Semarang. Jurnal Teknik Lingkungan, 6(1), 1-15.

4. Kementerian Lingkungan Hidup. 2014. Peraturan Menteri Lingkungan Hidup Nomor 5 Tahun 2014 Tentang Baku Mutu Limbah Cair Bagi Industri. Kemnterian Lingkungan Hidup Republik Indonesia.

5. Suprihatin, Suparno. O. 2013. Teknologi Proses Pengolahan Air untuk Mahasiswa dan Praktisi Industri. IPB Press.

6. Mukimin. 2006. Pengolahan Limbah Industri Berbasis Logam dengan teknologi Elektrokoagulasi Flotasi. [Tesis]. UNDIP. Semarang 